\title{
Delimitation of the species of the Debaryomyces hansenii complex by intron sequence analysis
}

\author{
Noémie Jacques, Sandrine Mallet and Serge Casaregola
}

Correspondence

Serge Casaregola

serge.casaregola@grignon.inra.fr

\section{INTRODUCTION}

The definition of species among micro-organisms has become increasingly difficult despite the accumulating amount of sequence data. In bacteria, high levels of lateral gene transfer (LGT) and highly variable gene content have blurred the delimitation of species. Hemiascomycetous yeasts constitute a good model for the study of speciation and the definition of species: many species have a sexual cycle, LGT is rare, and gene content is somewhat similar in the species studied so far (Dujon et al., 2004; Hall et al.,

Abbreviations: BSR, biological species recognition; GCPSR, genealogical concordance phylogenetic species recognition; LGT, lateral gene transfer; PS, phylogenetic species; PSR, phylogenetic species recognition.

The GenBank/EMBL/DDBJ accession numbers for sequences described in this article are: for the ACT1 introns, AM990068AM990117; for the RPL31 introns, AM990118-AM990167; for the RPL33 introns, AM990543-AM990594; for the TUB2 introns, AM990595-AM990641, FM165416 for the CBS 7761 ACT1 coding gene and FM165417 for the CBS 5572 ACT1 coding gene. The MycoBank (http://www.mycobank.org) accession number for Debaryomyces macquariensis sp. nov. is MB 512270.

Supplementary tables showing the primers used in this study and the sequence divergence within the ACT1 gene intron between clades and species are available with the online version of this paper.
2005). The phenotypic approach based on morphological and physiological identification has now been abandoned as in other micro-organisms. It is generally accepted that the biological species recognition concept (BSR) can be used for yeasts species displaying sexuality, although gene genealogies have shown that the BSR could be strongly questioned, at least in the genus Saccharomyces (Liti et al., 2006).

Unlike in euascomycetes, for which a phylogenetic definition of species, phylogenetic species recognition or PSR (Taylor et al., 2000), prevails, the delineation of hemiascomycetous yeasts species has recently been based, in many cases, on the use of rDNA sequence comparison of type strains. A first attempt at using nuclear sequences for this purpose revealed that diversity was much more pronounced than previously thought (Daniel et al., 2001; Daniel \& Meyer, 2003). Multigene approaches combining rDNA, housekeeping genes and mitochondrial cytochrome- $c$ oxidase subunit II (COX2) gene sequences have been developed (Kurtzman, 2003; Kurtzman \& Robnett, 2003). Although successful, these approaches still rely on the evolution of strongly conserved sequences and may not reflect the real genome sequence evolution (Tsui et al., 2008; Wu et al., 2008). Debaryomyces hansenii is a 
hemiascomycetous yeast which can be found in a variety of natural habitats as well as fruits and various manufactured foodstuff, especially cheese, in which it participates in the maturation of the products, or as a contaminant. In addition, $D$. hansenii has also been implicated as a potential emerging pathogen under this name or under that of its anamorphic form Candida famata (see Jacques \& Casaregola, 2008).

The taxonomic classification of the species related to $D$. hansenii has always been subject to debate. Originally two species were described: $D$. hansenii (Zopf) Lodder et Kreger van Rij and Debaryomyces fabryi Ota. It was proposed to subdivide the species $D$. hansenii (Zopf) Lodder et Kreger van Rij into two varieties $D$. hansenii var. hansenii and $D$. hansenii var. fabryi on the basis of the electrophoretic patterns of glucose-6-phosphate dehydrogenase and on the maximum growth temperature (Nakase \& Suzuki, 1985). It was further proposed that the two species $D$. hansenii (Zopf) Lodder et Kreger van Rij and D. fabryi Ota should be reinstated on the basis of random amplification of polymorphic DNA (RAPD) profiles (Prillinger et al., 1999). The classification of $D$. hansenii varieties was also questioned using various specific hybridization probes (Corredor et al., 2000). A low degree (0.7\%) of sequence divergence within the actin 1 (ACT1) gene was observed between the sequences of the two varieties, increasing the uncertainty concerning the differentiation of the two taxa (Daniel \& Meyer, 2003). PCR-RFLP (restriction fragment length polymorphism) analysis of the rDNA intergenic spacer (IGS) of Debaryomyces species could differentiate both varieties and led to their separation in two taxa, questioning their relationship (Quiros et al., 2006; Romero et al., 2005). On the other hand, rDNA internal transcribed spacer (ITS) variations could not differentiate the two varieties (Martorell et al., 2005) and a recent multi-locus analysis concluded that the observed divergence reflected intra-specific variability (Tsui et al., 2008).

Most of the D. hansenii isolates are thought to be haploid and to diploidize transiently by somatogamous autogamy to form asci containing generally a single spore (Kreger van Rij \& Veenhuis, 1975; van der Walt et al., 1977). Interstrain mating was rare as less than $0.6 \%$ of crosses between individual strains yielded progeny (van der Walt et al., 1977). As little is known concerning their sexuality and their taxonomic classification is confusing, D. hansenii and its related species constitute a good model to test new approaches for species delineation and to explore species complexes. Here, we compared intron sequences in a gene genealogies-based approach on 50 strains, to propose a new delineation of the species within the $D$. hansenii species complex.

\section{METHODS}

Strains and growth conditions. Most of the yeast isolates used in this study are from the CIRM-Levures (previously CLIB; http:// www.inra.fr/cirmlevures) and from the Centraalbureau voor
Schimmelcultures (http://www.CBS.knaw.nl) and are listed in Table 1. The strains L0702 and L0455 were isolated from wine fermentation from the Bordeaux area (France) and were kindly provided by Professor A. Lonvaud. Cells were routinely grown in YPD medium ( $1 \%$ yeast extract, $1 \%$ peptone, $1 \%$ glucose) at $28{ }^{\circ} \mathrm{C}$ with shaking.

DNA extraction. Cells grown in $3 \mathrm{ml}$ YPD medium overnight at $28{ }^{\circ} \mathrm{C}$ were centrifuged at $2500 \mathrm{~g}$ for $3 \mathrm{~min}$, and the resulting pellet was washed in $750 \mu \mathrm{l}$ EDTA $50 \mathrm{mM}$. The resulting pellet was resuspended in $200 \mu$ lysis buffer ( $1 \%$ SDS, $2 \%$ triton, $100 \mathrm{mM}$ $\mathrm{NaCl}, 50 \mathrm{mM}$ EDTA, $50 \mathrm{mM}$ Tris, $\mathrm{pH}$ 8), $200 \mu \mathrm{l}$ chloroform phenol $(\mathrm{pH}=8)$ and $300 \mathrm{mg}$ glass beads. The suspension was supplemented with $200 \mu 1 \mathrm{TE}$ buffer and centrifuged for $5 \mathrm{~min}$ at $12000 \mathrm{~g}$. The aqueous portion was transferred to a new tube, and two chloroform extractions were carried out. DNA was precipitated with 1 vol. 2propanol and centrifuged for $4 \mathrm{~min}$ at $12000 \mathrm{~g}$. The pellet was rinsed with $400 \mu \mathrm{l} 70 \%$ ethanol, dried at room temperature for $15 \mathrm{~min}$, resuspended in $50 \mu \mathrm{l}$ TE buffer, then incubated with $2 \mu \mathrm{l}$ RNase $\left(10 \mathrm{mg} \mathrm{ml}{ }^{-1}\right.$ ) for $30 \mathrm{~min}$ at $37^{\circ} \mathrm{C}$. The DNA concentration was quantified on agarose gel.

PCR amplification. The oligonucleotide primers used in this study (see Supplementary Table S1, available in IJSEM Online) were designed with Primer3 (http://fokker.wi.mit.edu/primer3) on the Release 2 of the sequence of the strain CBS $767^{\mathrm{T}}$ (http:// www.genolevures.org/; unpublished). A $2 \mu \mathrm{l}$ quantity of DNA (containing between 25 and $50 \mathrm{ng}$ ) was added to $48 \mu \mathrm{l}$ PCR reaction mix containing $0.8 \mathrm{mM}$ dNTP mixture, $0.1 \mu \mathrm{M}$ forward and reverse primers in the recommended buffer and $1 \mathrm{U}$ TaKaRa Ex Taq. Reactions were run on a 2720 thermal cycler (Applied Biosystems) as follows: $5 \mathrm{~min}$ at $94{ }^{\circ} \mathrm{C}$ followed by 30 cycles of $30 \mathrm{~s}$ at $94{ }^{\circ} \mathrm{C}, 40 \mathrm{~s}$ at temperatures varying between 48 and $55^{\circ} \mathrm{C}$ and between 30 and $60 \mathrm{~s}$ at $72{ }^{\circ} \mathrm{C}$, with a final extension step of $7 \mathrm{~min}$ at $72{ }^{\circ} \mathrm{C}$.

Cloning. PCR products were purified using NucleoSpin extract II purification kit (Macherey-Nagel). They were cloned in pBluescript $\mathrm{SK}^{-}$or in pGEM T Easy (Promega) using T4 DNA ligase (Promega). DH10B Escherichia coli cells were transformed by electroporation with pBluescript $\mathrm{SK}^{-}$recombinant plasmids and JM109 E. coli cells were transformed with pGEM T recombinant plasmids. Cells were selected for their ability to grow on ampicillin. Positive recombinant clones were chosen after PCR screening for the presence of insert and restriction analysis. Inserts were then sequenced using universal primers or the primers that served for the PCR amplification.

DNA sequence determination and phylogenetic analysis. PCR fragments were sequenced on both strands by Genomex using primers that served for the PCR amplification. Sequences were assembled with the PHRED/PHRAP/CONSED package. Sequences were analysed with the GCG Wisconsin package and various programs in the GCG environment, including BLAST and FASTA. Sequence alignments were generated by using CLUSTAL_X and were manually adjusted with GeneDoc (http://www.nrbsc.org/gfx/genedoc/). Phylogenetic trees were reconstructed with the neighbour-joining program implemented in CLUSTAL_X. Phylogenetic trees were visualized with TreeView, version 1.6.5 (Page, 1996) and NJPlot (Perriere \& Gouy, 1996).

\section{RESULTS}

\section{Rationale}

Liti et al. (2006) found that, in Saccharomyces cerevisiae, sequence divergence of above $5 \%$ for a number of genes ( $y K u 70, y K u 80, N E J 1, E S T 2, T L C 1$ and SPT4) dramatically reduces the viability of spores produced after mating 
Table 1. Debaryomyces strains used in this study and their characteristics

ND, Not determined.

\begin{tabular}{|c|c|c|c|c|}
\hline Strain & Previous identification & Source & Origin & Max. growth temp. \\
\hline D. fabryi CLIB 381 & D. hansenii var. fabryi & Goat's cheese & France & $37{ }^{\circ} \mathrm{C}$ \\
\hline D. fabryi CBS 4373 & D. hansenii var. fabryi & Wine & South Africa & $35{ }^{\circ} \mathrm{C}$ \\
\hline D. fabryi CLIB 615 & D. hansenii & Sainte-Maure goat's cheese & France & $30{ }^{\circ} \mathrm{C}$ \\
\hline D. fabryi CBS $789^{\mathrm{T}}$ & D. hansenii var. fabryi & Human & Germany & $37^{\circ} \mathrm{C}$ \\
\hline D. fabryi CBS 5138 & D. hansenii var. fabryi & Human & Hungary & $37^{\circ} \mathrm{C}$ \\
\hline D. fabryi CBS 5230 & D. hansenii var. fabryi & Rice vinegar mash & Japan & $35^{\circ} \mathrm{C}$ \\
\hline D. fabryi CBS 6066 & D. hansenii var. fabryi & Tanning fluid & France & $37^{\circ} \mathrm{C}$ \\
\hline D. fabryi CBS 7255 & D. hansenii var. fabryi & Food & Indonesia & $37{ }^{\circ} \mathrm{C}$ \\
\hline C. flareri CBS 2659 & D. hansenii var. hansenii & Apple & Italy & $40{ }^{\circ} \mathrm{C}$ \\
\hline C. flareri CBS 1128 & D. hansenii var. fabryi & $\mathrm{ND}$ & Netherlands & $40{ }^{\circ} \mathrm{C}$ \\
\hline C. flareri CBS $1796^{\mathrm{T}}$ & D. hansenii var. fabryi & Human & Italy & $40{ }^{\circ} \mathrm{C}$ \\
\hline C. flareri CBS 792 & D. hansenii var. fabryi & Human & Austria & $37{ }^{\circ} \mathrm{C}$ \\
\hline C. flareri CBS 1793 & D. hansenii var. hansenii & Human & $\mathrm{ND}$ & $37{ }^{\circ} \mathrm{C}$ \\
\hline C. flareri CBS 5140 & D. hansenii var. fabryi & Human & Hungary & $37{ }^{\circ} \mathrm{C}$ \\
\hline D. hansenii CBS $767^{\mathrm{T}}$ & D. hansenii var. hansenii & Beer & Denmark & $30{ }^{\circ} \mathrm{C}$ \\
\hline D. hansenii CLIB 236 & D. hansenii & Roncal cheese & Spain & $30{ }^{\circ} \mathrm{C}$ \\
\hline D. hansenii CLIB 240 & D. hansenii & Roncal cheese & Spain & $30{ }^{\circ} \mathrm{C}$ \\
\hline D. hansenii CLIB 249 & D. hansenii & Cheese & France & $30{ }^{\circ} \mathrm{C}$ \\
\hline D. hansenii CBS 6574 & D. hansenii var. hansenii & Seawater & USA & $30{ }^{\circ} \mathrm{C}$ \\
\hline D. hansenii CBS 1098 & D. hansenii var. hansenii & Cheese & Russia & $30{ }^{\circ} \mathrm{C}$ \\
\hline D. hansenii CBS $1102^{*}$ & D. hansenii var. hansenii & Beef and pork sausage & France & $30{ }^{\circ} \mathrm{C}$ \\
\hline D. hansenii CBS 5139 & D. hansenii var. hansenii & Human & Hungary & $30{ }^{\circ} \mathrm{C}$ \\
\hline D. hansenii CLIB $594^{*}$ & D. hansenii & Goat's cheese & France & $35^{\circ} \mathrm{C}$ \\
\hline D. hansenii CLIB 609 & D. hansenii & Camembert cheese & France & $30{ }^{\circ} \mathrm{C}$ \\
\hline D. hansenii CLIB 613 & D. hansenii & Forage & France & $30{ }^{\circ} \mathrm{C}$ \\
\hline D. hansenii CLIB 617 & D. hansenii & Goat's cheese & France & $35^{\circ} \mathrm{C}$ \\
\hline D. hansenii CLIB 624 & D. hansenii & Saint-Nectaire cheese & France & $30{ }^{\circ} \mathrm{C}$ \\
\hline D. hansenii CLIB $626^{*}$ & D. hansenii & Saint-Nectaire cheese & France & $35^{\circ} \mathrm{C}$ \\
\hline D. hansenii CLIB $662^{*}$ & D. hansenii & Goat's cheese & France & $35^{\circ} \mathrm{C}$ \\
\hline D. hansenii CLIB 722 & D. hansenii & Camembert cheese & France & $37{ }^{\circ} \mathrm{C}$ \\
\hline D. hansenii CLIB 920 & D. hansenii & Munster cheese & France & $35{ }^{\circ} \mathrm{C}$ \\
\hline D. hansenii CLIB 944 & D. hansenii & Wine & France & $\mathrm{ND}$ \\
\hline D. hansenii CLIB 947 & D. hansenii & Wine & France & ND \\
\hline D. hansenii CLIB 948 & D. hansenii & Wine & France & ND \\
\hline D. hansenii CLIB 953 & D. hansenii & Wine & France & ND \\
\hline D. hansenii CLIB 959 & D. hansenii & Wine & France & ND \\
\hline D. hansenii CLIB 1131 & D. hansenii & Refrigerator & France & $30{ }^{\circ} \mathrm{C}$ \\
\hline D. hansenii CLIB 1132 & D. hansenii & Refrigerator & France & $30{ }^{\circ} \mathrm{C}$ \\
\hline D. hansenii CLIB 1133 & D. hansenii & Refrigerator & France & $30{ }^{\circ} \mathrm{C}$ \\
\hline D. hansenii L0455 & D. hansenii & Wine & France & $28{ }^{\circ} \mathrm{C}$ \\
\hline D. hansenii L0702 & D. hansenii & Wine & France & $28{ }^{\circ} \mathrm{C}$ \\
\hline D. hansenii CBS 1795 & D. hansenii var. hansenii & Human & Denmark & $37^{\circ} \mathrm{C}$ \\
\hline D. hansenii CBS $1099^{*}$ & D. hansenii var. hansenii & Cheese & Russia & $30{ }^{\circ} \mathrm{C}$ \\
\hline D. hansenii CBS 1121 & D. hansenii var. fabryi & Food & France & $30{ }^{\circ} \mathrm{C}$ \\
\hline D. hansenii CBS $7848^{*}$ & D. hansenii var. hansenii & Salted pickle & Japan & $30{ }^{\circ} \mathrm{C}$ \\
\hline D. macquariensis CBS $5572^{\mathrm{T}}$ & D. hansenii var. fabryi & Soil & Australia & $37{ }^{\circ} \mathrm{C}$ \\
\hline D. tyrocola CBS $766^{\mathrm{T}}$ & D. hansenii var. hansenii & Cheese & Russia & $37{ }^{\circ} \mathrm{C}$ \\
\hline D. tyrocola CLIB 660 & D. hansenii & Goat's cheese & France & $37{ }^{\circ} \mathrm{C}$ \\
\hline D. tyrocola CLIB 949 & D. hansenii & Wine & France & $\mathrm{ND}$ \\
\hline D. nepalensis CBS 7761 & D. hansenii var. fabryi & Soy sauce & Indonesia & $35^{\circ} \mathrm{C}$ \\
\hline D. prosopidis CBS $8450^{\mathrm{T}}$ & D. prosopidis & Mesquite tree & USA & $37{ }^{\circ} \mathrm{C}$ \\
\hline
\end{tabular}

${ }^{\star}$ Multiple alleles. 
between divergent strains. As natural $D$. hansenii isolates rarely mate together and no selection is available, we analysed their sequence divergence and we used the threshold of $\sim 10 \%$ sequence divergence to place isolates into separate groups that we called phylogenetic species (PS).

Spliceosomal introns are much less subject to selective pressure than are coding sequences and we chose to study the sequence of introns carried by four well-conserved housekeeping genes: ACT1 (Génolevures genetic element DEHA2D05412g) encoding actin, TUB2 (DEHA2D08800g) encoding beta-tubulin, RPL31 (DEHA2D11110g) and RPL33 (DEHA2C16038g) encoding ribosomal proteins. The latter two genes are present in a single copy in $D$. hansenii var. hansenii CBS $767^{\mathrm{T}}$, in contrast to the situation in $S$. cerevisiae, where they are duplicated. These genes were chosen because the strong conservation of their coding sequence results in very little variation in the sequence used for PCR priming on either side of the intron. To PCR-amplify the introns of the ACT1 gene, we used two primers designed by Meyer's group (Daniel \& Meyer, 2003), CA11 and CA2R. In addition, we designed other specific $A C T 1$ primers. To PCR-amplify the
RPL31, RPL33 and TUB2 introns, we also designed specific primers, according to the complete genome sequence of $D$. hansenii var. hansenii CBS $767^{\mathrm{T}}$ (Dujon et al., 2004; http:// www.genolevures.org/). The RPL31 and RPL33 genes were chosen because ribosomal protein coding genes carry generally longer introns than non-ribosomal protein coding genes (Bon et al., 2003).

\section{Identification of phylogenetic species}

We amplified the intron-carrying regions of the four genes ACT1, TUB2, RPL31 and RPL33 in 50 isolates and determined the sequences of the PCR products that were generated. The isolates analysed came mainly from food, in particular cheese from various countries. Some were newly isolated yeasts from contaminating biofilms in refrigerators, oenological strains from the Bordeaux and the Colmar regions, and isolates from various other sources: soil, human wound and sea water (Table 1). We compared the sequences and constructed gene trees using the neighbourjoining algorithm. Figs 1 and 2 show the trees obtained for the ACT1 and RPL33 genes, respectively. The ACT1 intron sequence alignment contained 121 informative characters

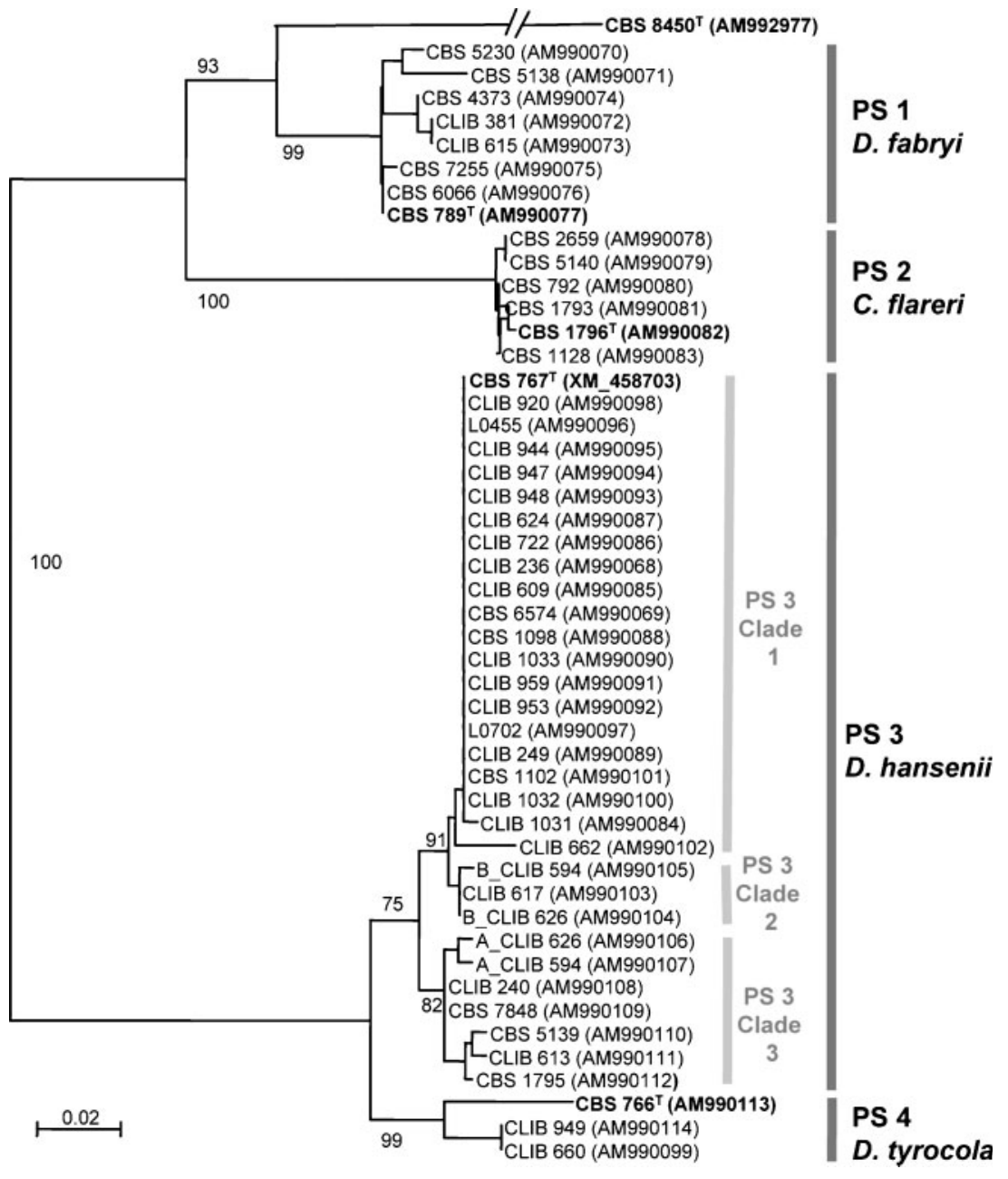

Fig. 1. Neighbour-joining phylogram of the intron of the ACT1 gene of Debaryomyces isolates. Bootstrap values (\%) based on 1000 replicates are indicated at the nodes for main groups and clades. All positions containing gaps and missing data were eliminated from the dataset. Type strains are in bold characters. Groups and clades are indicated. The branch length of $D$. prosopidis CBS $8450^{\top}$ is shortened. Bar, 0.02 substitutions per site. 


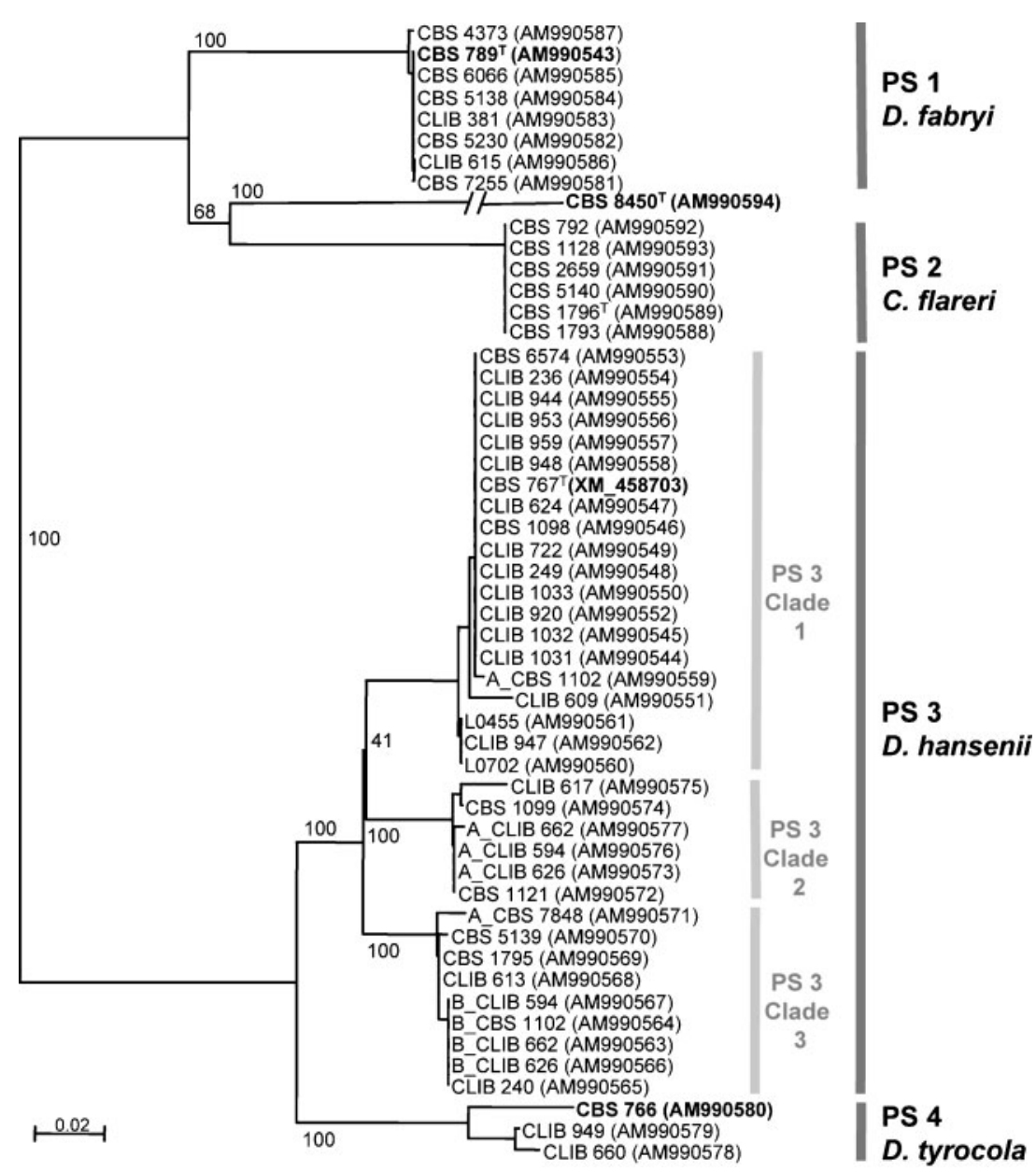

Fig. 2. Neighbour-joining phylogram of the intron of the RPL33 gene of Debaryomyces isolates. Bootstrap values (\%) based on 1000 replicates are indicated at the nodes for main groups and clades. All positions containing gaps and missing data were eliminated from the dataset. Type strains are in bold characters. Groups and clades are indicated. The branch length of $D$. prosopidis CBS $8450^{\top}$ is shortened. Bar, 0.02 substitutions per site. out of 300, TUB2 72 out of 271, RPL31 140 out of 355 and RPL33 155 out of 384. In order to be used for species delineation, PSR must be based on concordance of gene genealogies (coined genealogical concordance phylogenetic species recognition or GCPSR, Taylor et al., 2000). Phylogenetic trees showed a good concordance between the four genes. With the exception of a few cases (discussed below), the distribution of the isolates in the various trees was identical.

The gene trees suggest the existence of four phylogenetic species; the first contained the type-strain of $D$. hansenii var. fabryi CBS $789^{\mathrm{T}}$ (PS 1) and the second contained its anamorph C. famata var. flareri CBS $1796^{\mathrm{T}}$ (PS 2). The sequence divergence between these two phylogenetic species ranged from 12 to $19 \%$. According to our criterion, this indicates that these two taxa form distinct species. The divergence between the rDNA sequences of the teleomorph D. hansenii var. fabryi CBS $789^{\mathrm{T}}$ and its anamorph $C$. famata var. flareri CBS $1796^{\mathrm{T}}$ amounts to two bases in the D1/D2 region and three bases in the ITS region. Divergence of the ACT1-coding gene sequence between these type strains amounted to only $2.4 \%$ (Daniel \& Meyer, 2003), indicating that sequences such as introns are more discriminating than rDNA or coding sequence of house- keeping genes. The sequence divergence between the ACT1-coding sequence and the cognate intronic sequence for the type-strains or a representative strain of all the defined groups is summarized in Supplementary Table S2, available in IJSEM Online.

The third phylogenetic species (PS 3) is more complex and contains D. hansenii var. hansenii CBS $767^{\mathrm{T}}$ and its anamorph C. famata var. famata CBS $1795^{\mathrm{T}}$. The sequence divergence observed between the strains in this group was less than 1.5, 3, 5 and $5.6 \%$ for the TUB2, ACT1, RPL31 and RPL33 introns, respectively. This indicates that, according to our criterion, although the strains in PS 3 display a certain level of genetic diversity, they are conspecific. Hence, in contrast to the situation of the PS 1 and PS 2 where the teleomorph/anamorph pair $D$. hansenii var. fabryi/C. famata var. flareri are in fact in distinct taxa, PS 3 contains the teleomorph/anamorph pair D. hansenii var. hansenii/C. famata var. famata.

The strains CBS 776, CLIB 660 and CLIB 949 display marked sequence divergence of $4,5,8$ and $14 \%$ for the TUB2, ACT1, RPL31 and RPL33 introns, respectively, when compared with the D. hansenii var. hansenii CBS $767^{\mathrm{T}}$ reference sequence. This suggests that these strains have 
undergone a speciation process and that they constitute a distinct species from PS 3 and PS 4 (Figs 1 and 2).

We included in our analysis the Debaryomyces prosopidis type strain CBS $8450^{\mathrm{T}}$. D. prosopidis cells have been isolated from exudates of mesquite trees. This species was shown to be related to the two varieties of $D$. hansenii on the basis of phenotypic characteristics, but was considered to be a separate species on the basis of DNA/DNA reassociation and because of its lack of growth on cellobiose (Phaff et al., 1998). Considering the large sequence divergence with respect to $D$. hansenii var. fabryi CBS $789^{\mathrm{T}}$ and its anamorph C. famata var. flareri CBS $1796^{\mathrm{T}}$, its two closest relatives, we confirm here that $D$. prosopidis forms a distinct species (Supplementary Table S2, available in IJSEM Online, Figs 1 and 2). Three gene intron genealogies out of four (TUB2, RPL31 and ACT1) indicate that it has evolved from PS 1 after the divergence of PS 1/PS 2, the other genealogy (RPL33) placing D. prosopidis CBS $8450^{\mathrm{T}}$ closer to the PS 2 branch.

\section{PS 3 constitutes a complex group of strains, some being diploid heterozygotes for the tested markers}

The sensitivity of our method, due to the high intrinsic variability of intron sequences, led to the separation of strains of group 3 into three clades (Figs 1 and 2). Clade 1 contained the majority of the isolates, including the typestrain D. hansenii var. hansenii CBS $767^{\mathrm{T}}$. This clade is made up of food strains, oenological strains and refrigerator contaminants. All the strains in clade 2 (CBS 1121, CBS 1099, CLIB 594, CLIB 617 and CLIB 626) were isolated from food, mainly cheese. Clade 3 contains $C$. famata var. famata CBS $1795^{\mathrm{T}}$, CBS 5139 (previously identified as $D$. hansenii var. fabryi on the basis of rDNA comparison), CBS 7848, several cheese strains, CLIB 613 and CLIB 240, the latter having been differentiated from CLIB 236 (clade 1) using mitochondrial DNA RFLP and RAPD in a previous study (Romano et al., 1996).

Overall, the assignment of strains to phylogenetic species and clades proved robust. The first exception concerns CLIB 662, whose ACT1 and TUB2 genealogies associate the strain to clade 1 and whose RPL31 genealogy places it in the clade 2, indicating that CLIB 662 contains genetic material from two different ancestors. This was observed for CLIB 617 also, whose TUB2 and RPL31 genealogies placed it in clade 1, whereas that with ACT1 and RPL33 placed it in clade 2 . The second exception concerns strains yielding PCR products whose sequences could not be obtained, suggesting that mixed populations of PCR products were generated. The PCR products that could not be sequenced were cloned and the inserts of a number of individual clones were sequenced. Except for CBS 1099 and CBS 7848, we found in these strains two different sequences, each corresponding to one of the three described clades, indicating that the strains were diploid heterozygote for the tested markers. One of the RPL31 alleles of CBS 1099 could not be assigned to one of the PS 3 clades and defined therefore another specific clade (Table 2). Moreover, CBS 7848 contained more than two RPL33 alleles, one was assigned to clade 3 and the two others were not characterized further. Table 2 summarizes all the allele combinations. The Japanese strain CBS 7848 (also known as TK) shared TUB2 alleles from clade 2 and from an undescribed new clade (data not shown). The latter allele differed markedly from all the strains described, having $10 \%$ divergence with the clade 2 allele of CBS 7848, $9 \%$ divergence with CBS $767^{\mathrm{T}}$ and $6 \%$ divergence with CBS 766. Considering that the TUB2 intron is the less discriminating marker used in this study, CBS 7848 is very likely a hybrid between a $D$. hansenii var. hansenii clade 2 strain and an as-yet undescribed species.

Taken together, these results indicate that a number of strains of PS 3 are at least partially diploid and show that genetic exchanges are more common than expected. No such exchange was seen in isolates from PS 1 and PS 2.

\section{Origin of strains and phenotypic differentiation}

With the exception of PS 2, no correlation was seen between our species delimitation and the origin of the isolates. For the isolates of PS 2, all the strains are isolated from human and not from manufactured food (one strain was isolated from an apple). All the other phylogenetic species and clades contain strains that have been isolated from a variety of sources (human, food, natural habitats...). This observation is in agreement with the ubiquitous nature of $D$. hansenii.

The maximal growth temperature character has previously been used to differentiate the two $D$. hansenii varieties

Table 2. Assignment of the sequenced alleles of various strains to $D$. hansenii clades

ND, Not determined.

\begin{tabular}{|c|c|c|c|c|c|}
\hline Strain & Allele & $A C T 1$ & TUB2 & RPL31 & RPL33 \\
\hline \multirow[t]{2}{*}{ CLIB 594} & A & Clade 2 & * & $\mathrm{ND}$ & Clade 2 \\
\hline & B & Clade 3 & * & Clade 3 & Clade 3 \\
\hline \multirow[t]{2}{*}{ CLIB 626} & A & Clade 2 & * & Clade 2 & Clade 2 \\
\hline & B & Clade 3 & * & Clade 3 & Clade 3 \\
\hline \multirow[t]{2}{*}{ CLIB 662} & A & * & * & * & Clade 3 \\
\hline & B & * & * & * & Clade 2 \\
\hline \multirow[t]{2}{*}{ CBS 1102} & A & * & * & Clade 2 & Clade 1 \\
\hline & B & * & * & ND & Clade 3 \\
\hline \multirow[t]{2}{*}{ CBS 1099} & A & ND & * & Clade 1 & * \\
\hline & B & ND & * & $\begin{array}{c}\text { Specific } \\
\text { clade }\end{array}$ & * \\
\hline \multirow[t]{2}{*}{ CBS 7848} & A & * & Clade 2 & Clade 2 & Clade 3 \\
\hline & B & * & $\begin{array}{c}\text { Specific } \\
\text { clade }\end{array}$ & $\mathrm{ND}$ & $\dagger$ \\
\hline
\end{tabular}

* Single allele.

$\dagger$ Multiple alleles. 
hansenii and fabryi (Nakase \& Suzuki, 1985). We found that this character is unsuitable for this purpose, as a number of the isolates of the PS 1 cannot tolerate higher temperatures than $30{ }^{\circ} \mathrm{C}$, whereas strains of PS 3 can grow at $35{ }^{\circ} \mathrm{C}$ or even at $37{ }^{\circ} \mathrm{C}$ (Table 1). Interestingly, all the isolates from the PS 2 can grow at $37{ }^{\circ} \mathrm{C}$ or above, consistent with the fact that all but one were isolated from human sources.

\section{Re-identification of known isolates and detection of a cryptic species}

The gene sequence comparison of isolates from collections revealed mis-identifications (Table 1). Strain CBS 7761, identified as $D$. hansenii var. fabryi (http://www.cbs.knaw.nl), was found to be closely related to Debaryomyces nepalensis CBS $5921^{\mathrm{T}}$ with only three base changes out of $310 \mathrm{bp}$ of the $A C T 1$ intron. This was confirmed with the ACT1 coding gene sequence comparison which showed only one mismatch out of 790 bp between CBS 7761 and D. nepalensis CBS $5921^{\mathrm{T}}$. This identifies CBS 7761 as D. nepalensis.

The ACT1 gene intron of CBS 5572 (previously identified as $D$. hansenii var. fabryi on the basis of rDNA sequence comparison) diverged from all known Debaryomyces species (over 16\% divergence with the closest species), even those which are closely related to $D$. hansenii proper. The ACT1 coding gene of CBS 5572 showed a $7 \%$ sequence divergence when compared with that of $\mathrm{CBS} 767^{\mathrm{T}}$ (Fig. 3). We propose that CBS 5572 therefore represents a new cryptic species. This strain, isolated by di Menna (Skerman \& Singleton, 1964), was originally identified as Debaryomyces kloeckeri, a species which is heterogeneous and is no longer valid (Nakase et al., 1998).

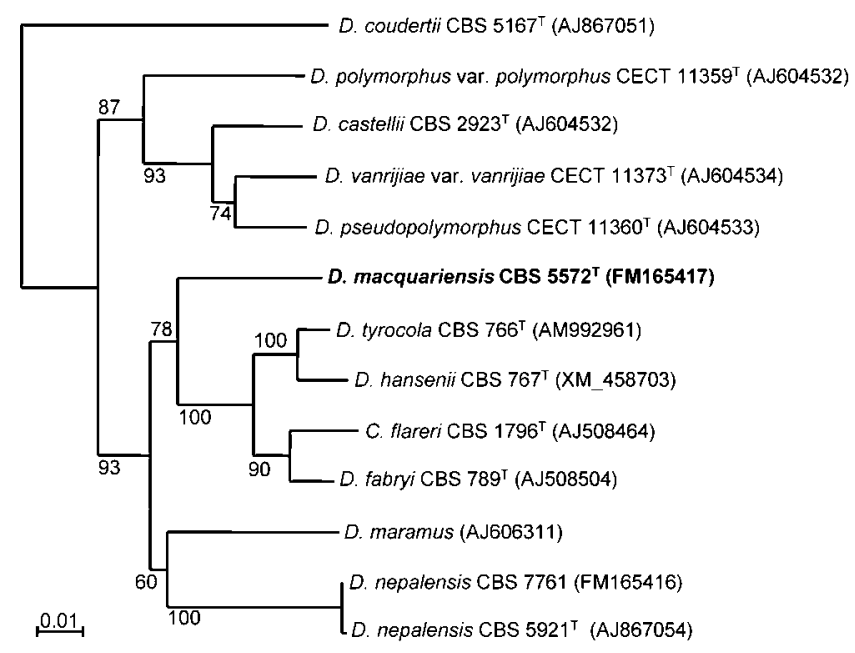

Fig. 3. Neighbour-joining phylogram of the $A C T 1$ coding gene sequence of Debaryomyces type strains. Bootstrap values (\%) based on 1000 replicates are indicated at the nodes. Most of the DNA sequences were retrieved from GenBank. Bar, 0.01 substitutions per site.

\section{Latin diagnosis of Debaryomyces macquariensis N. Jacques, S. Mallet et S. Casaregola sp. nov.}

In medio liquido YPD post dies 3 ad $25{ }^{\circ} \mathrm{C}$ cellulae rondae, 8-9 $\mu \mathrm{m}$, singulae. Per gemmationem unipolarem reproducentes, hyphae absunt. Ascosporae globosae, 1-2 in asco, ex ascis non liberantur.

Glucosum fermentatur (tarde).

D-Glucosum, D-galactosum, D-ribosum (lente, varium); Dxylosum, L-rhamnosum (lente), sucrosum, maltosum, trehalosum, $\alpha$-methyl-D-glucosidum, salicinum, arbutinum, lactosum, raffinosum, melezitosum, inulinum, amylum, glycerolum, erythritolum, ribitolum, xylitolum, L-arabinitolum, D-glucitolum, D-mannitolum, D-glucono-1,5-lactonum (lente), 2-keto-D-gluconatum, D-gluconatum, DL-lactatum (lente), acidum succinicum, acidum citricum, propane 1,2 diolum (lente), ethanolum assimilantur, at non L-sorbosum, D-glucosaminum, L-arabinosum, D-arabinosum, melibiosum, galactitolum, myo-inositolum, D-glucuronatum, D-galacturonatum, butane 2,3 diolum, acidum quinicum, D-glucaratum, D-galactonatum nec methanolum.

Ethylaminum hydrochloricum, cadaverinum dihydrochloricum assimilantur at non natrium nitrosum, kalium nitricum, L-lysinum (lente, variabile), creatinum, creatininum, glucosaminum, imidazolum nec D-tryptophanum. Vitamina externa crescentia non sunt necessaria. In agaro extracto fermenti confecto 50 partes glucose per centum non crescit. Parte una cycloheximidi per mille et per centum non crescit.

Maxima temperature crescentiae: $37^{\circ} \mathrm{C}$. Materia amyloidea iodophila, acidum aceticum non formantur. Diazonium caeruleum B non respondens. Ureum non hydrolysatur. Typus stirps CBS $5572^{\mathrm{T}}$.

\section{Description of Debaryomyces macquariensis N. Jacques, S. Mallet \& S. Casaregola sp. nov.}

Debaryomyces macquariensis (mac.qua.ri.en'sis. N.L. fem. adj. macquariensis refers to Macquarie Island in Australia, from where the type strain was isolated).

After 3 days at $25{ }^{\circ} \mathrm{C}$ in YPD, the cells are round, $8-9 \mu \mathrm{m}$ and occur singly. Vegetative reproduction is by unilateral budding. No hyphal elements are produced on cornmeal agar. Spherical asci containing one to two ascospores are formed after incubation for 5 days on Mac Clary agar medium.

Glucose fermentation is weak and delayed.

D-Glucose, D-galactose, D-ribose (weak and delayed); Dxylose, L-rhamnose (delayed), sucrose, maltose, trehalose, methyl- $\alpha$-D-glucoside, salicin, arbutin, lactose, raffinose, melezitose, inulin, starch, glycerol, erythritol, ribitol, xylitol, L-arabinitol, D-glucitol, D-mannitol, D-glucono1,5-lactone (delayed), 2-keto-D-gluconate, D-gluconate, DLlactate (delayed), succinate, citrate, propane 1,2 diol (delayed) and ethanol are assimilated. L-Sorbose, D-glucosamine, L- arabinose, D-arabinose, melibiose, galactitol, myo-inositol, D-glucuronate, D-galacturonate, 
butane 2,3 diol, quinic acid, D-glucarate, D-galactonate and methanol are not assimilated.

Ethylamine and cadaverine hydrochloride are assimilated; potassium nitrate, sodium nitrite, creatine, creatinine, glucosamine, imidazole and D-tryptophan are not assimilated; L-lysine is weak or delayed or negative. Growth in vitamin-free medium, $50 \%$ glucose, $0.01 \%$ and $0.1 \%$ cycloheximide is negative.

Maximum growth temperature is $37^{\circ} \mathrm{C}$. Starch-like compounds and acid acetic are not produced. Diazonium blue $B$ reaction is negative. Urease activity is negative.

The type strain, CBS $5572^{\mathrm{T}}$, was isolated from soil in Macquarie Island in Australia. This strain has been deposited in the Centraalbureau voor Schimmelcultures (CBS) during December 1964.

\section{Further taxonomic considerations}

On the basis of RAPD-PCR, Prillinger et al. (1999) considered that the two varieties $D$. hansenii var. hansenii and $D$. hansenii var. fabryi should be reinstated as two distinct species. Daniel \& Meyer (2003) observed divergence within the $A C T 1$ gene coding sequence, indicating that the $D$. hansenii var. hansenii/D. hansenii var. fabryi and D. hansenii var. fabryi/C. famata var. flareri pairs display an important intra-specific variability. These authors proposed that the latter pair should be split into two varieties. Our results confirm and even extend these authors' proposals. We show here, using multi-gene genealogies of intron sequences on a large number of isolates, greater than $19 \%$ divergence between $D$. hansenii var. hansenii and the teleomorph/anamorph $D$. hansenii var. fabryilC. famata var. flareri pair. We also show that the group of strains containing the teleomorph $D$. hansenii var. fabryi and the anamorph C. famata var. flareri, respectively, differ from each other by at least $14 \%$. A parallel can be drawn with the Saccharomyces sensu stricto species in which the Saccharomyces cerevisiae/Saccharomyces bayanus pair sequences diverge by at least $20 \%$ and the S. cerevisiae/S. paradoxus pair sequences diverge by at least $10 \%$. We therefore propose in agreement with Prillinger et al. (1999) to abandon the variety classification for $D$. hansenii and to reinstate these taxa as two distinct species.

Considering the divergence between the teleomorph $D$. hansenii var. fabryi and anamorph C. famata var. flareri, we further propose to reinstate C. famata var. flareri as a distinct species under the name Candida flareri.

Candida flareri (Ciferri \& Redaelli) Jacques, Mallet \& Casaregola.

Basionym: Blastodendrion flareri Ciferri \& Redaelli. Arch Mikrobiol 6 (1935) 9.

Typus: CBS 1796.

As mentioned above, the strains CBS 766, CLIB 660 and CLIB 949 differ markedly from strains of PS 3, with sequence divergence up to $14 \%$. According to our criterion, these strains should constitute a new taxon. Since the first strain to be described in this taxon was CBS $766^{\mathrm{T}}$, as the type strain of the Debaryomyces tyrocola species, we propose that this species be reinstated.

\section{DISCUSSION}

The primary aim of our study was to test whether we could apply a phylogenetic approach to recognized species within a hemiascomycetous yeast species complex that cannot be resolved by existing traditional and molecular methods. We have studied the $D$. hansenii species complex using GCPSR by sequencing and comparing intron sequences of four genes of 50 strains of the D. hansenii complex. This led to the delineation of phylogenetic species and concordant results for nearly all the markers tested were obtained. Indeed, we observed a lack of concordance in only a few cases for which the isolates very likely resulted from crosses between the isolates from two distinct clades within a phylogenetic species. The divergence between intron sequences that we observed when PS 1, PS 2 and PS 3 were compared is well above the sequence divergence $(\sim 10 \%)$ that abolishes totally viability of spores in crosses of S. cerevisiae (Liti et al., 2006) and that we have chosen as a threshold for species delimitation. We therefore propose, in agreement with a number of authors (Prillinger et al., 1999; Corredor et al., 2000; Romero et al., 2005; Quiros et al., 2006), that the two $D$. hansenii varieties constitute now the species Debaryomyces hansenii and Debaryomyces fabryi. Considering the heterogeneity within the previously defined $D$. hansenii var. fabryi variety, we also propose that a number of strains therein should form the new species Candida flareri. The variability of the sequences analysed here allowed us to distinguish clearly three clades within the newly defined species $D$. hansenii, one which contains C. famata var. famata. The maximal sequence divergence between these clades reached $5.6 \%$, indicating that the strains belonging to these clades are conspecific. The existence of strains carrying heterozygote alleles defining these clades supports our proposition (see below).

Overall, the RPL33 gene intron proved to be the most divergent, whereas the TUB2 sequence showed the least divergence; this could reflect the different nature of the two sequences, the former being the longest intron used in our study (418 bp in CBS $767^{\mathrm{T}}$ ), the latter containing two short introns separated by 36 bp coding sequence ( 299 bp with $118 \mathrm{bp}$ and $111 \mathrm{bp}$ for intron 1 and 2, respectively). The TUB2 gene was chosen as it constitutes a valuable marker in the taxonomy of filamentous fungi (Geiser et al., 1998), but our results suggest it may not be as useful for hemiascomycetous yeasts.

We demonstrated for the first time natural diploidy in $D$. hansenii for a number of markers, crosses having only been performed with auxotrophic mutants (van der Walt et al., 1977). Although yeasts are prone to gene duplication and 
diploidization, the presence of heterozygous markers in some strains by gene duplication can be ruled out, as allele sequences are $100 \%$ identical to the sequences of strains of the various clades. The most parsimonious explanation is that the diploid heterozygote strains result from recent crosses, which have been followed by the massive loss of one specific haplotype (Sipiczki, 2008) or/and gene conversions. The six detected diploid heterozygotes may be partial diploids, as often only one allele of the analysed genes is present (Table 2), consistent with a massive gene loss associated to gene conversion. Interestingly, no such heterozygosity was seen in the other newly proposed species D. fabryi, C. flareri and D. tyrocola (PS 1, PS 2 and PS 4). Heterozygotes were limited to D. hansenii (PS 3). This may be due to the small number of isolates available in the other three taxa. Many strains from PS 3 (Table 1) are involved in fermentation and could be prone to diploidy. It is indeed well known that industrial isolates have a complex, very often diploid, polyploid or even aneupolyploid genome (Bidenne et al., 1992; KiellandBrandt et al., 1995; Masneuf et al., 1998).

The six isolates presenting some level of diploidy carry sequences from clade 3 , suggesting that this clade is more prone to mating. This is paradoxical as this clade contains C. famata var. famata, which does not have a sexual state. Our observation is also surprising, as C. famata var. famata has been associated in the past with a number of clinical cases (Krcmery \& Barnes, 2002; Pfaller \& Diekema, 2002), whereas the six isolates have been isolated from food. Clinical isolate identification should be reassessed with gene genealogies in order to better understand their relation to the isolates of the phylogenetic group studied here as it has been suspected that species authentication of clinical isolates may be questionable (see Hazen, 1995; Jacques \& Casaregola, 2008).

Our approach was successful in identifying cryptic species, in detecting populations within a single species, and also in bringing to light speciation events. It has been proposed that speciation may be linked to major changes in the genome structure, such as unequal translocation that would lead to genetic isolation. This was ruled out by genomic analysis in Saccharomyces sensu stricto (Fischer et al., 2000). The cryptic species studied here, in particular the closely related PS 3 and PS 4, may prove a good material to study speciation in a different model from that of $S$. cerevisiae, as it was shown that $D$. hansenii displays one of the highest rates of chromosomal rearrangements among hemiascomycetous yeasts (Fischer et al., 2006). In this respect, the case of the species $D$. prosopidis is noteworthy. Our study suggests that $D$. prosopidis has evolved from $D$. fabryi after the divergence of $D$. fabryi/C. flareri. The long branch of $D$. prosopidis may indicate an interesting case of rapid evolution. The substrate on which D. prosopidis (Sonoran mesquite) was isolated and its geographical location of isolation may suggest that we are observing a case of allopatric speciation.
In yeasts, the use of a gene genealogies-based approach on populations for species delineation is expanding (Kuehne et al., 2007; Jacobsen et al., 2008). Crosses between wild Saccharomyces paradoxus isolates from geographically distinct populations tended to produce lower spore viability (Kuehne et al., 2007), in agreement with Liti et al. (2006), strengthening our species delimitation of yeasts with uncharacterized sexuality using similar sequences. Here, we were able to detect cryptic species and very likely interbreeding within the $D$. hansenii species complex. We believe that the combination of the use of discriminating sequences such as introns and horizontal analysis of a large number of isolates will help in the future to better define the boundaries of yeast species and to reveal cryptic species.

\section{ACKNOWLEDGEMENTS}

We are grateful to Professor C. R. Tinsley (AgroParisTech, ThivervalGrignon, France) and Professor J. Dupont (Muséum National d'Histoire Naturelle, Paris, France) for reading the manuscript and for helpful discussion. We are grateful to Professor A. Lonvaud (Université Victor Segalen Bordeaux 2, Bordeaux, France) and Dr J.L. Legras (INRA Colmar, Colmar, France) for providing us with isolates. This work was supported by INRA and CNRS.

\section{REFERENCES}

Bidenne, C., Blondin, B., Dequin, S. \& Vezinhet, F. (1992). Analysis of the chromosomal DNA polymorphism of wine strains of Saccharomyces cerevisiae. Curr Genet 22, 1-7.

Bon, E., Casaregola, S., Blandin, G., Llorente, B., Neuvéglise, C., Munsterkotter, M., Guldener, U., Mewes, H. W., Van Helden, J. \& other authors (2003). Molecular evolution of eukaryotic genomes: hemiascomycetous yeast spliceosomal introns. Nucleic Acids Res 31, 1121-1135.

Corredor, M., Davila, A. M., Gaillardin, C. \& Casaregola, S. (2000). DNA probes specific for the yeast species Debaryomyces hansenii: useful tools for rapid identification. FEMS Microbiol Lett 193, 171177.

Daniel, H. M. \& Meyer, W. (2003). Evaluation of ribosomal RNA and actin gene sequences for the identification of ascomycetous yeasts. Int J Food Microbiol 86, 61-78.

Daniel, H. M., Sorrell, T. C. \& Meyer, W. (2001). Partial sequence analysis of the actin gene and its potential for studying the phylogeny of Candida species and their teleomorphs. Int J Syst Evol Microbiol 51, 1593-1606.

Dujon, B., Sherman, D., Fischer, G., Durrens, P., Casaregola, S., Lafontaine, I., De Montigny, J., Marck, C., Neuvéglise, C. \& other authors (2004). Genome evolution in yeasts. Nature 430, 35-44.

Fischer, G., James, S. A., Roberts, I. N., Oliver, S. G. \& Louis, E. J. (2000). Chromosomal evolution in Saccharomyces. Nature 405, 451454.

Fischer, G., Rocha, E. P., Brunet, F., Vergassola, M. \& Dujon, B. (2006). Highly variable rates of genome rearrangements between hemiascomycetous yeast lineages. PLoS Genet 2, e32.

Geiser, D. M., Pitt, J. I. \& Taylor, J. W. (1998). Cryptic speciation and recombination in the aflatoxin-producing fungus Aspergillus flavus. Proc Natl Acad Sci U S A 95, 388-393. 
Hall, C., Brachat, S. \& Dietrich, F. S. (2005). Contribution of horizontal gene transfer to the evolution of Saccharomyces cerevisiae. Eukaryot Cell 4, 1102-1115.

Hazen, K. C. (1995). New and emerging yeast pathogens. Clin Microbiol Rev 8, 462-478.

Jacobsen, M. D., Boekhout, T. \& Odds, F. C. (2008). Multilocus sequence typing confirms synonymy but highlights differences between Candida albicans and Candida stellatoidea. FEMS Yeast Res 8, 764-770.

Jacques, N. \& Casaregola, S. (2008). Safety assessment of dairy microorganisms: the hemiascomycetous yeasts. Int J Food Microbiol 126, 321-326

Kielland-Brandt, M. C., Nilsson-Tillgren, T., Gjermansen, C., Holmberg, S. \& Pedersen, M. B. (1995). Genetics of brewing yeasts. In The Yeasts, 2nd edn, vol. 6, pp. 223-254. Edited by A. E. Wheals, A. H. Rose \& J. S. Harrison. London: Academic Press.

Krcmery, V. \& Barnes, A. J. (2002). Non-albicans Candida spp. causing fungaemia: pathogenicity and antifungal resistance. $J$ Hosp Infect 50, 243-260.

Kreger van Rij, N. J. \& Veenhuis, M. (1975). Electron microscopy of ascus formation in the yeast Debaryomyces hansenii. J Gen Microbiol 89, 256-264.

Kuehne, H. A., Murphy, H. A., Francis, C. A. \& Sniegowski, P. D. (2007). Allopatric divergence, secondary contact, and genetic isolation in wild yeast populations. Curr Biol 17, 407-411.

Kurtzman, C. P. (2003). Phylogenetic circumscription of Saccharomyces, Kluyveromyces and other members of the Saccharomycetaceae, and the proposal of the new genera Lachancea, Nakaseomyces, Naumovia, Vanderwaltozyma and Zygotorulaspora. FEMS Yeast Res 4, 233-245.

Kurtzman, C. P. \& Robnett, C. J. (2003). Phylogenetic relationships among yeasts of the 'Saccharomyces complex' determined from multigene sequence analyses. FEMS Yeast Res 3, 417-432.

Liti, G., Barton, D. B. \& Louis, E. J. (2006). Sequence diversity, reproductive isolation and species concepts in Saccharomyces. Genetics 174, 839-850.

Martorell, P., Fernandez-Espinar, M. T. \& Querol, A. (2005). Sequence-based identification of species belonging to the genus Debaryomyces. FEMS Yeast Res 5, 1157-1165.

Masneuf, I., Hansen, J., Groth, C., Piskur, J. \& Dubourdieu, D. (1998), New hybrids between Saccharomyces sensu stricto yeast species found among wine and cider production strains. Appl Environ Microbiol 64, 3887-3892.

Nakase, T. \& Suzuki, M. (1985). Taxonomic studies on Debaryomyces hansenii (Zopf) Lodder et Kreger-Van Rij and related species. II. Practical discrimination and nomenclature. J Gen Appl Microbiol 31, 71-86.
Nakase, T., Suzuki, M., Phaff, H. J. \& Kurtzman, C. P. (1998). Debaryomyces Lodder \& Kreger-van Rij Nom. Cons. In The Yeasts, a Taxonomic Study, 4th edn, pp. 157-178. Edited by C. P. Kurtzman \& J. W. Fell. Amsterdam: Elsevier.

Page, R. D. (1996). TreeView: an application to display phylogenetic trees on personal computers. Comput Appl Biosci 12, 357-358.

Perriere, G. \& Gouy, M. (1996). WWW-query: an on-line retrieval system for biological sequence banks. Biochimie 78, 364-369.

Pfaller, M. A. \& Diekema, D. J. (2002). Role of sentinel surveillance of candidemia: trends in species distribution and antifungal susceptibility. J Clin Microbiol 40, 3551-3557.

Phaff, H. J., Vaughan-Martini, A. \& Starmer, W. T. (1998). Debaryomyces prosopidis sp. nov., a yeast from exudates of mesquite trees. Int J Syst Bacteriol 48, 1419-1424.

Prillinger, H., Molnar, O., Eliskases-Lechner, F. \& Lopandic, K. (1999). Phenotypic and genotypic identification of yeasts from cheese. Antonie van Leeuwenhoek 75, 267-283.

Quiros, M., Martorell, P., Valderrama, M. J., Querol, A., Peinado, J. M. $\&$ de Siloniz, M. I. (2006). PCR-RFLP analysis of the IGS region of rDNA: a useful tool for the practical discrimination between species of the genus Debaryomyces. Antonie van Leeuwenhoek 90, 211-219.

Romano, A., Casaregola, S., Torre, P. \& Gaillardin, C. (1996). Use of RAPD and mitochondrial DNA RFLP for typing of Candida zeylanoides and Debaryomyces hansenii yeast strains isolated from cheese. Syst Appl Microbiol 19, 255-264.

Romero, P., Patino, B., Quiros, M., Gonzalez-Jaen, M. T., Valderrama, M. J., de Siloniz, M. I. \& Peinado, J. M. (2005). Differential detection of Debaryomyces hansenii isolated from intermediate-moisture foods by PCR-RFLP of the IGS region of rDNA. FEMS Yeast Res 5, 455-461.

Sipiczki, M. (2008). Interspecies hybridization and recombination in Saccharomyces wine yeasts. FEMS Yeast Res 8, 996-1007.

Skerman, T. M. \& Singleton, R. J. (1964). Sulphur nutrition of two strains of the yeast, Debaryomyces kloeckeri, isolated from subantarctic soil. Can J Microbiol 10, 397-406.

Taylor, J. W., Jacobson, D. J., Kroken, S., Kasuga, T., Geiser, D. M., Hibbett, D. S. \& Fisher, M. C. (2000). Phylogenetic species recognition and species concepts in fungi. Fungal Genet Biol 31, 21-32.

Tsui, C. K., Daniel, H. M., Robert, V. \& Meyer, W. (2008). Reexamining the phylogeny of clinically relevant Candida species and allied genera based on multigene analyses. FEMS Yeast Res 8, 651-659.

van der Walt, J. P., Taylor, M. B. \& Liebenberg, N. V. (1977). Ploidy, ascus formation and recombination in Torulaspora (Debaryomyces) hansenii. Antonie van Leeuwenhoek 43, 205-218.

Wu, Q., James, S. A., Roberts, I. N., Moulton, V. \& Huber, K. T. (2008). Exploring contradictory phylogenetic relationships in yeasts. FEMS Yeast Res 8, 641-650. 